\title{
流し掛け水車の周辺の流れの \\ MPS法による数値解析 \\ NUMERICAL SIMULATION OF FLOW AROUND CURRENT WATER WHEEL BY MPS METHOD
}

\author{
浪平 篤 1 後藤眞宏 $2 \cdot$ 高木強治 ${ }^{3}$ \\ Atsushi NAMIHIRA, Masahiro GOTO and Kyoji TAKAKI \\ 1正会員 博士(農) 農研機構農村工学研究所資源循環工学研究領域（†305-8609 つくば市観音台2-1-6） \\ 2 博士 (農) 農研機構農村工学研究所資源循環工学研究領域（同上） \\ 3正会員 博士(農) 農研機構農村工学研究所水利工学研究領域 （ 同 上 )
}

The applicability of MPS method as an assessment tool for flow regimes in installing a current water wheel in an open channel as one of the development of micro-scale hydropower generation in irrigation systems, was examined. As a result, the simulated flow regimes agreed qualitatively with the experimental results at given rotational speeds of the water wheel. However, the simulated energy difference between upstream and downstream of the water wheel was about $20 \%$ larger than the experimental results at given rotational speeds in the case the length of water turbine runner was $0.1 \mathrm{~m}$. The main reasons were considered to be numerical pressure fluctuation known as a problem of original MPS method, and lack of phenomenal representation based on employing the 2D single-phase model.

Key Words : micro-scale hydropower generation, irrigation channel, current water wheel, back water, MPS method

\section{1. 緒論}

灌溉のための用水路の延長は，面積が100ha以上の農 地に送水している基幹的なものだけで約 3 万千 $\mathrm{km}$ ，中 小規模のものを含むとその約10倍といわれている1)。ま た用水路の流量は，灌溉期 (一般に5〜8月頃) と非灌兓期 とで大きく変化するが，時間的にはあまり変動しない. そのため，昨今のエネルギー事情から再生利用可能エネ ルギーの必要性が高まる中，用水路における小水力発電 も注目されている. 用水路のうち落差工のように大きな 落差を有する地点では，既に実施されつつある21.

しかしながら，用水路の大部分を構成する落差の小さ い開水路部分では，流れのエネルギーの抽出は容易でな いため，ほとんど実施されていない．水車自体もしくは 付帯施設の設置によって水車の上流側で堰上げを生じさ せ，水車の上下流のエネルギ一差を高めることは有効で あるが，水路の余裕高 ${ }^{3}$ は建設時の経済性から必要最低 限に設計されていることが多く，堰上げが過剩であれば 溢水する可能性がある. 従って, 開水路部分で小水力発 電を行うためには，水車の設置が開水路の流れに及ぼす
影響の予測が不可欠である。しかしながら，そのような 検討はあまり実施されておらず，そのための方法も十分 に確立されていない.

前述の予測方法になり得るのは，模型実験と数值解析 である．前者が実施されていないのは，気泡が多く含ま れる流れを扱うことから，フルード数に基づく相似則に よる縮尺模型を用いる場合は十分な再現性が得られない 可能性があり，実物規模の模型を用いる場合は多額の費 用を要するためと考えられる，後者については，解析事 例の多いフランシス水車 ${ }^{4) \sim 6)}$ 等のような管水路流れの中 に設置される水車とは異なり，自由水面の大変形，水滴 の飛沫，気泡の混入を伴う流れを安定して解析できる必 要があり，そのような方法が少なかったためと考えられ る.一方で，このような厳しい条件下の流れに対しても， MPS法 ${ }^{7)}$ は対応できると考えられる. 本手法はこれまで に大気中で射出される水流によって回転させられるペル トン水車のバケット内流れ ${ }^{8), 99}$ の他, 近年では種々の水 理構造物の周辺の流れ ${ }^{10),}{ }^{11)}$ に対しても適用性が確認さ れつつある.

そこで本研究では, 用水路のうち開水路部分に設置さ れる水車として代表的なものの一つと考えられる流し掛 


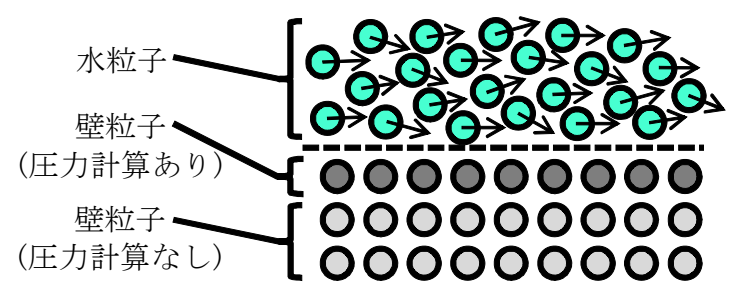

図-1ＭPS法における壁粒子の配置の概念図 ${ }^{7)}$

け水車に着目し，水車の設置が開水路の流れに及ぼす影 響を予測する方法として, MPS法の適用性を検討する.

\section{2. 解析の方法}

\section{(1) MPS法の概要}

MPS (Moving Particle Semi-implicit) 法7) とは, 非圧縮性 流れを有限個の粒子で近似してラグランジュ的に解く方 法である. 支配方程式における微分演算子を粒子間相互 作用モデルによって表現することが特徴である.

支配方程式のうち運動方程式には，式(1)のNavierStokes方程式を用いる。連続式には，密度一定条件を粒 子数密度一定条件といいかえた式(2)を用いる.

$$
\begin{gathered}
\frac{D \boldsymbol{u}}{\partial t}=-\frac{1}{\rho} \nabla p+v \nabla^{2} \boldsymbol{u}+\boldsymbol{g} \\
\frac{1}{n_{0}} \frac{D n}{\partial t}+\nabla \boldsymbol{u}=0
\end{gathered}
$$

ここで， $\boldsymbol{u}$ は流速ベクトル， $p$ は圧力， $\rho$ は流体の密度， $\boldsymbol{g}$ は重力加速度ベクトル $\left(\right.$ 鉛直下方向成分は $\left.9.8 \mathrm{~m} / \mathrm{s}^{2}\right), v$ は動粘性係数 $\left(1.0 \times 10^{-6} \mathrm{~m}^{2} / \mathrm{s}\right), n$ は粒子数密度, $n_{0}$ は密 度一定条件を満足するための粒子数密度 (一定值)である.

粒子間相互作用モデルでは，粒子 $i$ の粒子数密度は式 (3), 圧力勾配項は式(4), 粘性項は式(5)となる.

$$
\begin{gathered}
\langle n\rangle_{i}=\sum_{i \neq j}\left\{w\left(\left|\boldsymbol{r}_{j}-\boldsymbol{r}_{i}\right|\right)\right\} \\
\left\langle-\frac{1}{\rho} \nabla p\right\rangle_{i}=-\frac{1}{\rho} \frac{d}{n_{0}} \sum_{i \neq j}\left\{\frac{\left(p_{j}-p_{i}\right)\left(\boldsymbol{r}_{j}-\boldsymbol{r}_{i}\right)}{\left|\boldsymbol{r}_{j}-\boldsymbol{r}_{i}\right|^{2}} w\left(\left|\boldsymbol{r}_{j}-\boldsymbol{r}_{i}\right|\right)\right\} \\
\left\langle v \nabla^{2} \boldsymbol{u}\right\rangle_{i}=\frac{2 v d}{n_{0} \lambda} \sum_{i \neq j}\left\{\left(\boldsymbol{u}_{j}-\boldsymbol{u}_{i}\right) w\left(\left|\boldsymbol{r}_{j}-\boldsymbol{r}_{i}\right|\right)\right\}
\end{gathered}
$$

ここで， $w$ は粒子間相互作用に関する重み関数， $d$ は次 元数，入はモデル定数である. $w$ および入はそれぞれ式 (6)，（7）で定義される.

$$
\begin{gathered}
w(r)=\left\{\begin{array}{lll}
r_{e} / r-1 & \text { for } & 0 \leq r<r_{e} \\
0 & \text { for } & r_{e} \leq r
\end{array}\right. \\
\lambda=\sum_{i \neq j}\left\{\left|\boldsymbol{r}_{j}-\boldsymbol{r}_{i}\right|^{2} w\left(\left|\boldsymbol{r}_{j}-\boldsymbol{r}_{i}\right|\right)\right\} / \sum_{i \neq j}\left\{w\left(\left|\boldsymbol{r}_{j}-\boldsymbol{r}_{i}\right|\right)\right\}
\end{gathered}
$$

式(6)の $r_{e}$ は粒子間相互作用の及ぶ範囲を示すパラメー タであり, 初期配置における粒子間距離 $l_{0}$ を基準とする と, 式(3)の粒子数密度の計算では $2.1 l_{0}$, 式(4)等の勾
配では $2.1 l_{0}$, 式(5)等のラプラシアンでは $4.0 l_{0}$ が推奨さ れている. なお， $l_{0}$ は解析空間を格子分割する数值解析 方法における格子幅に相当する.

自由水面の境界条件として, 次式を満たす粒子は自由 水面上に存在するものと判定する.

$$
\langle n\rangle_{i}<\beta n_{0}
$$

式(8)の $\beta$ としては，0.95が推奨されている.

壁面の境界条件(図-1) として, 水粒子と接し, 粒子数 密度と圧力を計算する壁粒子と, 水粒子とは接さず, 粒 子数密度と圧力を計算しない壁粒子の2種類を用意する. そして前者を1層配置, 後者を2層配置とする. このよう な配置により, 前者の粒子数密度が低下し, 式(8)に よって自由水面と判定されることを防止する.

なお，MPS法は前述のように非圧縮性流れを対象とし ているが，僅かな圧縮性を付与することで数值的な安定 性が改善される7). 本研究では，この対策を採用した。

\section{（2）薄肉構造物の壁面境界}

MPS法における壁面の境界条件のうち標準的なものは 図-1の通りである。しかし，水車の羽根のように，その 両面で水粒子と接する薄肉構造物を扱う場合に，全ての 粒子の $l_{0}$ を同一とすれば， $l_{0}$ を非常に小さな值としなけ ればならず，計算負荷が過大になる.

この問題に対しては，これまでに，壁粒子を1層配置 とし，その両面に圧力を与えるとともに，このような壁 粒子の近傍における水粒子の粒子数密度を計算する際に は $r_{e}$ で規定される範囲のうち薄肉構造物の背面の面積を 計算してその寄与分を別途与えることにより，粒子数密 度の低下を防ぐ方法 ${ }^{12)}$ が提案されている.さらに，この 方法では，薄肉構造物上でドライ・ウェット境界が発生 すれば，その近傍における水粒子の数が少ないため，粒 子数密度の低下を防止できない可能性があることから， 薄肉構造物を構成する壁粒子の中間点に， $l_{0}$ が他よりも 小さい粒子を配置する方法 ${ }^{10)}$ も提案されている.

しかし，これらの方法では，羽根は時々刻々回転する ため，その近傍における水粒子が羽根を構成する壁粒子 のどちら側の面の圧力の影響を受けるかの判定等が煩雑 になる可能性がある，そこで本研究では，非均一粒子径 モデルを採用して，羽根を構成する壁粒子の $l_{0}$ を他の粒 子よりも小さくするとともに，羽根では壁粒子を4層配 置とし, それらのうち外側の壁粒子のみを粒子数密度と 圧力の計算対象とした(図-2).また，水粒子が羽根を挟 むように存在する場合 (図-2) は，式(6)の $r_{e}$ の範囲内の 粒子を検索する際, 互いをカウントしない処理を行い, このような粒子間の相互作用を除去した。

\section{（3）解析モデル}

解析モデルは，詳細なデータが計測されている後藤に よる流し掛け水車の模型実験 ${ }^{13)}$ を模擬して作成した. な 


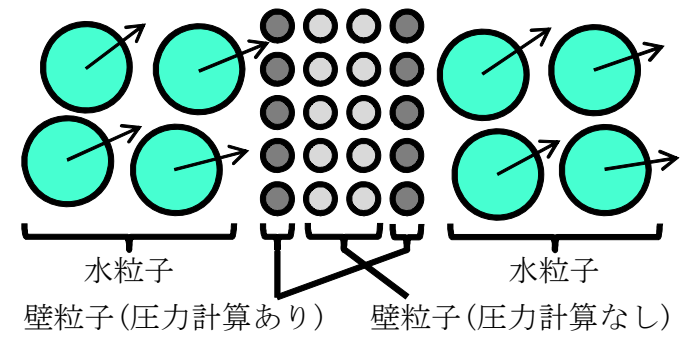

図-2＼cjkstart水車の羽根を構成する壁粒子概念図

お，流し掛け水車とは，大きな落差のない開水路におい て，堰やゲート等の付帯施設を設置せず，水車自体に よってその上流側で堰上げを生じさせる水車をいう ${ }^{14)}$.

実験では, 幅 $0.24 \mathrm{~m}$, 深さ $0.32 \mathrm{~m}$, 長さ $16 \mathrm{~m}$ のアクリル 製水平水路が用いられた. この水路の流下方向中央地点 に直径 $0.5 \mathrm{~m}$, 幅 $0.236 \mathrm{~m}$, 羽根の厚さ $0.003 \mathrm{~m}$, 羽根の長さ 0.04 $0.12 \mathrm{~m}$ ，羽根の数 12 枚のアクリル製水車が，水路 底と水車下端との隙間が $0.003 \mathrm{~m}$ となるように設置された。 水路の上流端ではポンプにより一定流量が供給され，下 流端ではゲートによって水位が調節された，そして，発 電機との接続を想定した水車への負荷を変化させ，水車 が開水路の流れに及ぼす影響等が計測されている.

解析モデルの対象範囲は，計算機の能力上の制限から， 前述の水平水路のうち水車の中心から上下流に $2 \mathrm{~m}$ の地 点の間とした (図-3(a)). また, 実験状況の映像から, 縦断面における流れが卓越していると考えられたため, 鉛直2次元解析を行うこととした. 水車の羽根の長さに は，計測結果 ${ }^{13)}$ が比較的多い $0.10 \mathrm{~m}$ を採用した (図-3(b)).

\section{（4）解析の条件}

水車の羽根では $l_{0}$ を羽根の厚さの $1 / 4$ である $0.00075 \mathrm{~m}$, その他では $l_{0} を 0.005 \mathrm{~m}$ とした。

水理条件には, 計測結果 ${ }^{13)}$ が比較的多い流量 $0.016 \mathrm{~m}^{3} / \mathrm{s}$, 水車設置前の水深 $0.16 \mathrm{~m}$, 同状態のフルード数 0.35 を採 用した. この水深を確保するため, 解析モデルの末端の 堰の高さ $h_{\text {weir }}($ 図-3(a)) を試行錯誤で定めた. なお，水 車設置前の水深については, 後述 (3，(2)) 寸る水車設 置後における水車上流側の水深と同じく, 水車の中心か ら上流に $1 \mathrm{~m}$ の地点で評価した(図-3(a)).

流入境界 (図-3 (a)) には可溶性移動壁15)を用いた。こ れは，壁が一定速度で上昇し，その上端の高さが間值に 達すると, 最上層の粒子が水粒子に変質するとともに, その下部に粒子が1層追加されるものである. これによ
り, 一定流量の供給が表現される. また, 解析モデルの 末端の堰の直下流では自由流出境界とした。

水車への負荷 ${ }^{13)}$ については，各負荷を使用した場合に 観測された水車の回転数を強制的に与えることにより， 再現することとした. 回転数としては, 前述の水理条件 においてほぼ最小值，中間值，最大值であった 5,10 , $14 \mathrm{rpm}^{13)}$ を採用した。

初期条件として，可溶性移動壁の他に水粒子が全く存 在しない状態を設定し，水位変動がほぼ一定の範囲内に 収まった時点以降の解析結果を，評価の対象とした。

\section{3. 解析結果と考察}

\section{（1）瞬間的な流況}

まず，負荷の違いが水車の周辺の流況に及ぼす影響を を調べる. 水車の回転数が $5 ， 10 ， 14 \mathrm{rpm}$ のきの瞬間的 な流況の一例をそれぞれ図-4，5，6に示寸．左側が水粒 子の分布状況，右側が水粒子の流速ベクトルである. な お，図-4〜6では，原点の位置および流れの方向を図3(a) と同様としており，水車は反時計回りに回転してい る. また, 各図の (a) は水車の羽根の一つが水路底に対 して垂直となる瞬間 $\left(t=t_{1}\right.$ とする $)$ を，(b)および (c) は (a) を基準としてそれぞれ水車が $\pi / 30 ， \pi / 15 \mathrm{rad}$ 回転し た瞬間を示している. ただし， $t_{1}$ の值は各図で異なる.

図-4〜6のうち水粒子の分布状況より，回転数の増加 に伴い，(1)水車の内部や水車の下流側において水面形の 乱れが大きくなる，(2)羽根の下流側において水粒子の存 在しない領域が増える等の傾向がみられた. また，図-4 ～6のうち水粒子の流速べクトルより，水車内では，(3) 回転数が5rpmのときには羽根の角度によらず水面付近で 主流が生じる，(4)10rpmのときには羽根の角度によって は主流が5rpmのときほど明確にならない場合が生じる, (5)14rpmのときには主流を識別できないほど乱れが激し くなる等の傾向がみられた。 これらの傾向は, 定性的で はあるが，実験結果 ${ }^{13)}$ とほぼ同様である.

なお，上記(2)の羽根の下流側における水粒子の存在し ない領域は, 羽根が水没する際, 気相の一部が巻き込ま れるようにして生じたものである. 実験状況の映像でも, 同様の過程で気泡が混入している，但し実験では，羽根 の回転に伴い，気泡は羽根に沿って水面に浮上している

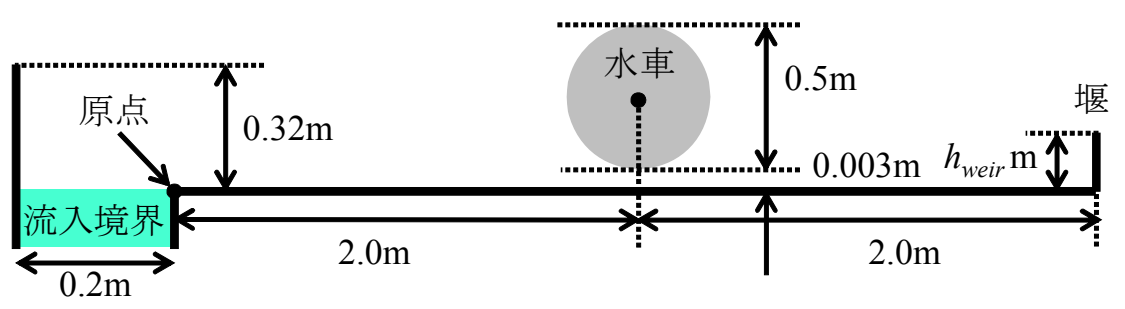

(a) 全体

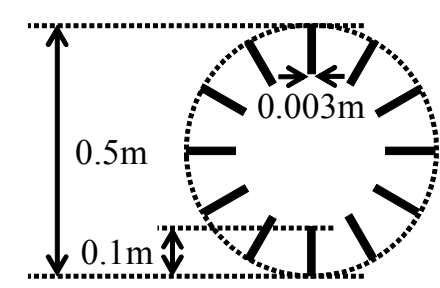

(b) 水車のみ

図-3＼cjkstart解析モデルの概念図 

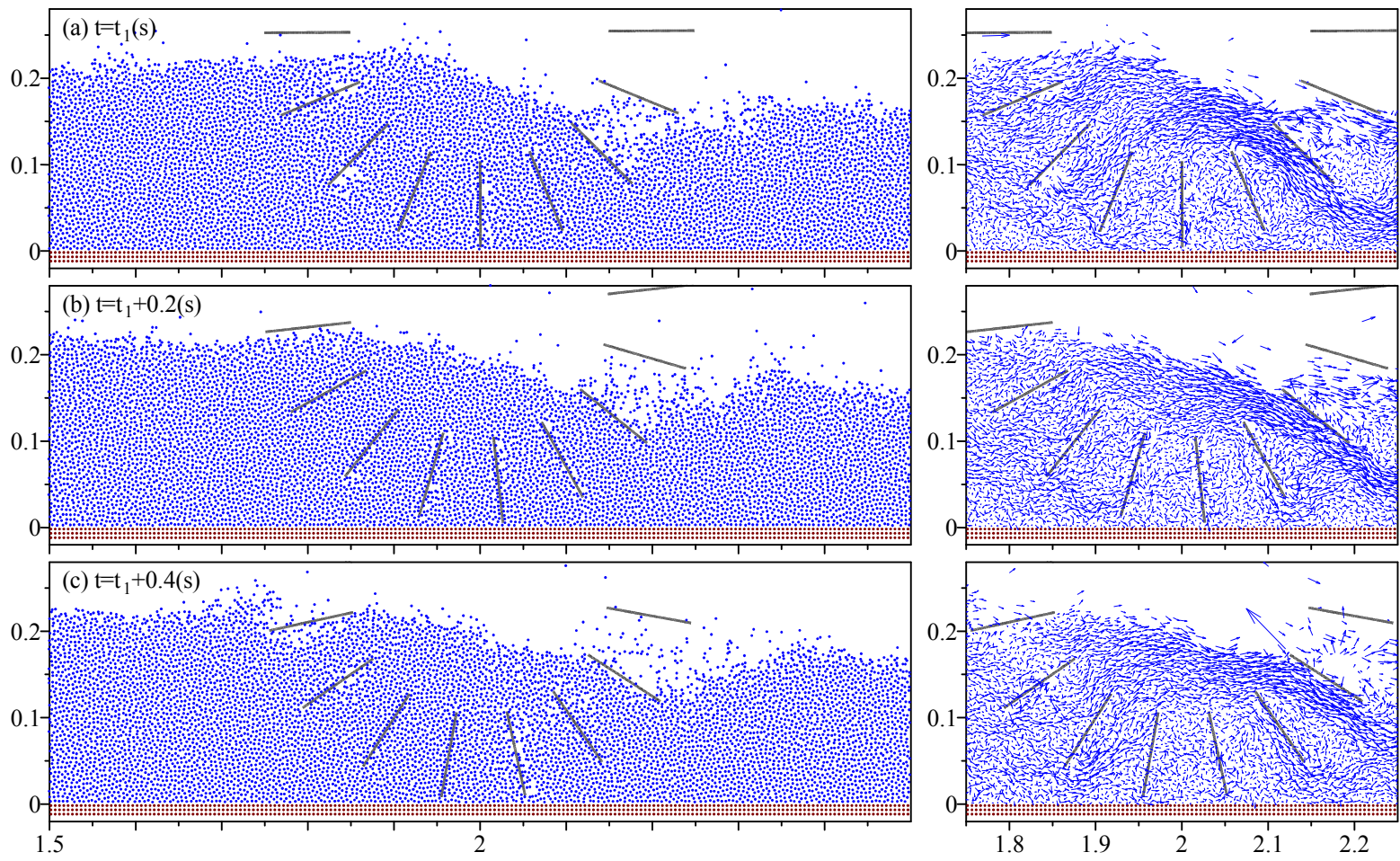

・壁粒子 ・壁粒子(水車の羽根) $・$ 水粒子 $-1 \mathrm{~m} / \mathrm{s}$

図-4 水車の回転数が5rpmのときの瞬間的な流況の一例 （縱軸は鉛直方向距離 $(\mathrm{m})$, 横軸は水平方向距離 $(\mathrm{m})$ ）
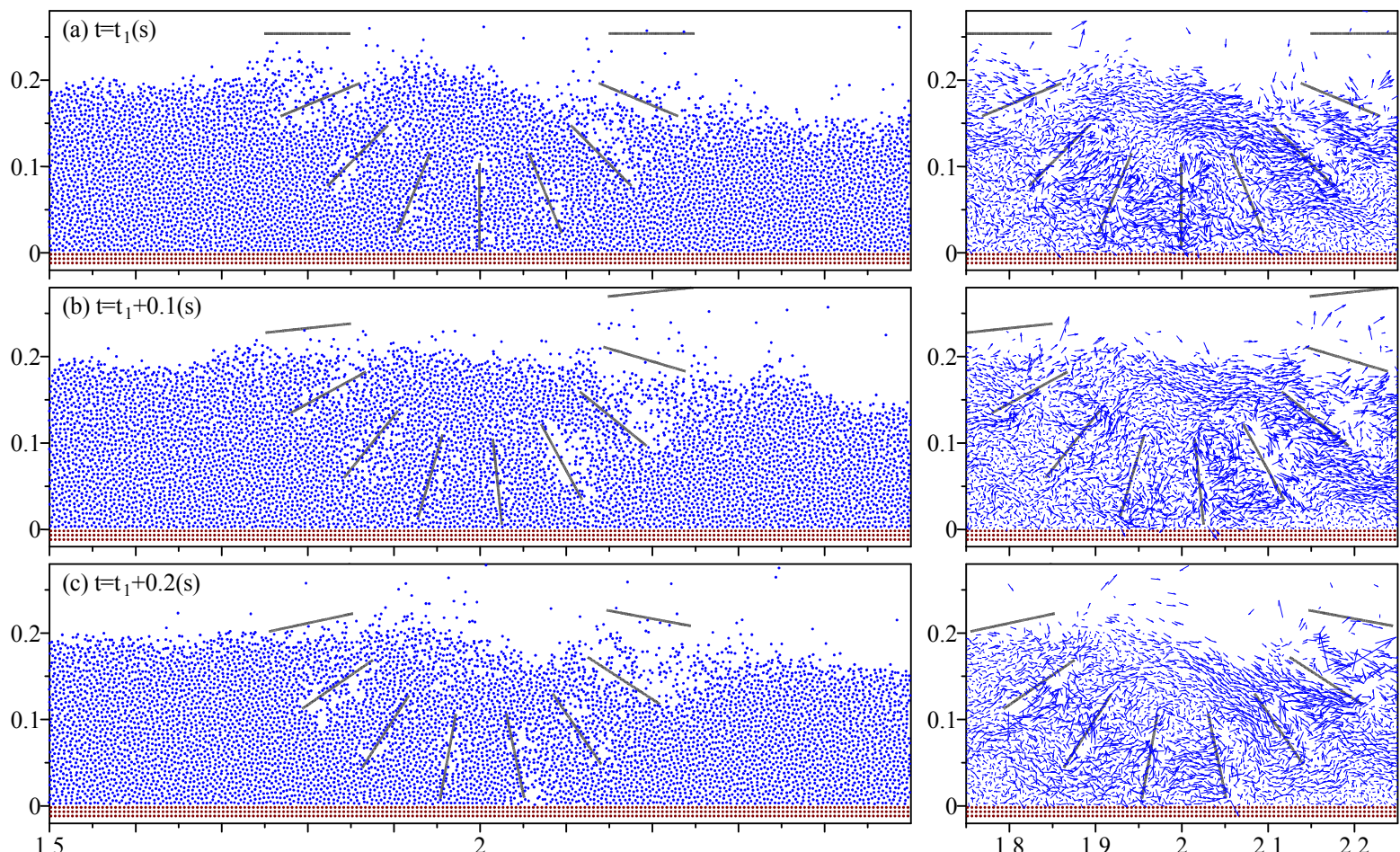

・壁粒子 ·壁粒子(水車の羽根) ・水粒子 $-1 \mathrm{~m} / \mathrm{s}$

図-5 水車の回転数が10rpmのときの瞬間的な流況の一例 (縦軸は鉛直方向距離 $(\mathrm{m})$, 横軸は水平方向距離 $(\mathrm{m}))$

のに対し，解析結果では，水粒子の存在しない領域は水 面に浮上していない. 気泡の挙動の再現と気泡の影響の 評価には，本研究で採用した液相のみの単相流解析では なく，気液二相流解析を行う必要があると考えられ，そ
の適用は今後の課題である.

また，瞬間的かつ局所的に発生する大きな流速につい ては，MPS法に特有の圧力の擾乱 ${ }^{11)}$ の影響によって発 生したと考えられる．時間とともに収まってはいるが, 

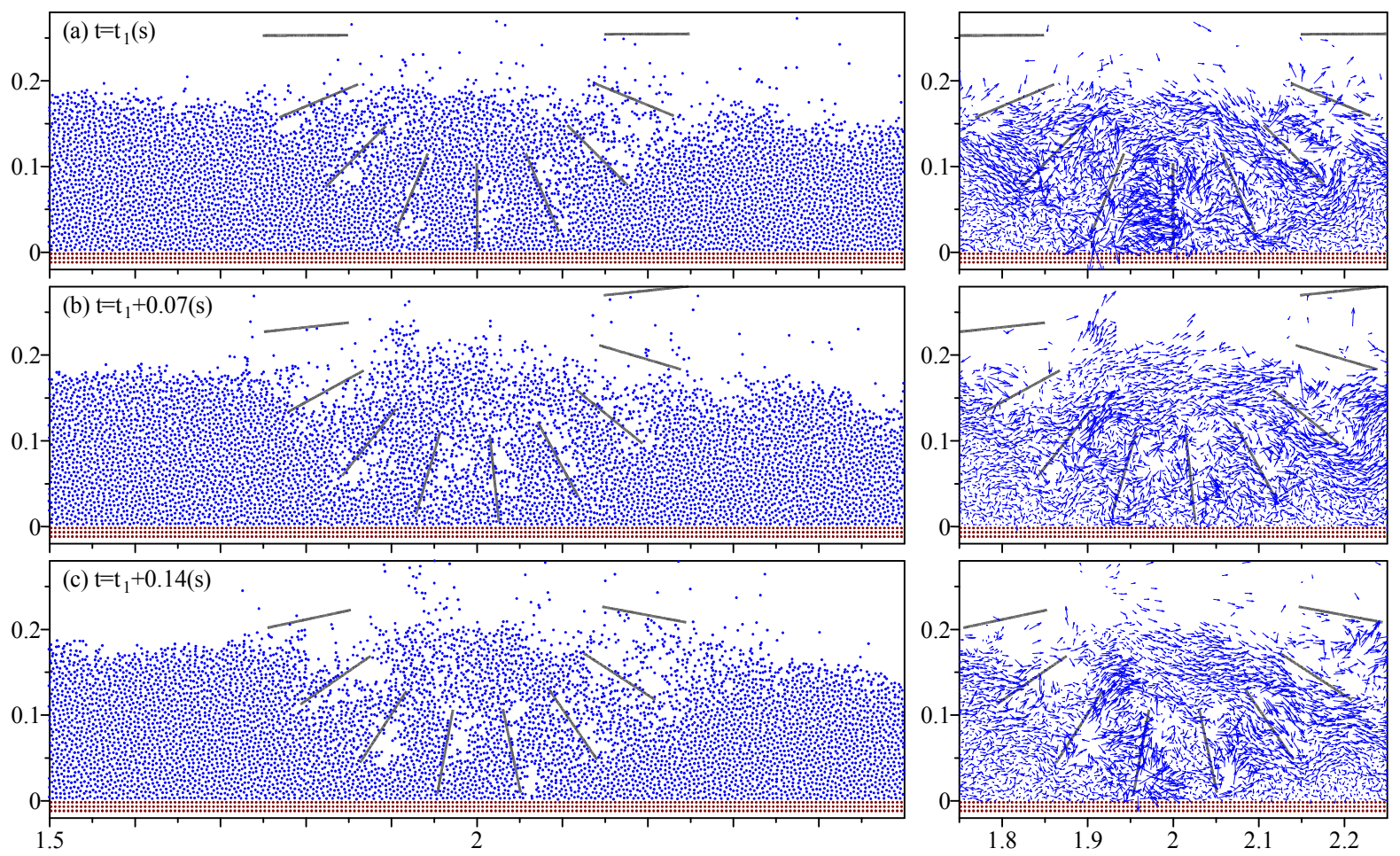

・壁粒子 ・壁粒子(水車の羽根) $・$ 水粒子 $-1 \mathrm{~m} / \mathrm{s}$

図-6 水車の回転数が14rpmのときの瞬間的な流況の一例 （縱軸は鉛直方向距離 $(\mathrm{m})$, 横軸は水平方向距離 $(\mathrm{m}))$

その改善は今後の課題である.

\section{（2）水車の設置が流れに及ぼす影響}

水車の設置が開水路の流れに及ぼす影響として，まず は最も重要と考えられる堰上げの発生状況を確認する。

一方，実験結果 ${ }^{13)}$ との比較によるMPS法の適用性の検討 については，実験では水車の上下流のエネルギー差が整 理されていることから，この值を対象として行う.

水車の回転数が $5,10,14 \mathrm{rpm}$ のきの水車の上下流の 水深の経時変化を図-7に示寸，これらの水深は，それぞ れ水車の中心から上下流に $1 \mathrm{~m}$ の地点で評価した. 上流 側の水深の評価位置は，水車設置前の水深の評価位置 （2.（4)）之同一である. 水面の位置は，式(8) で自由水 面と判定された粒子に基づいて定めたが，周囲の粒子と 比較して $l_{0}$ よりも離れている粒子は利用しなかった.

図-7より，定性的ではあるが，水車の下流側の水深は 回転数の影響をほとんど受けず，上流側の水深は回転数 の減少すなわち負荷の増加に伴い，堰上げによって水車

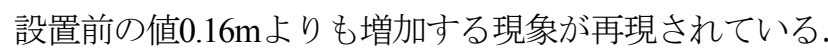

これらの水深をもとに算出した水車の上下流のエネル ギ一差と水車の回転数との関係を, 実験結果 ${ }^{13)}$ に追記し たものが図-8である. 実験結果としては, 解析の対象で ある水車の羽根の長さが $0.10 \mathrm{~m}(2$. (3)) のときの值だけ

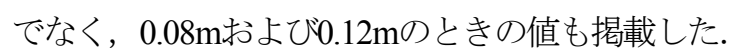

図-8より，回転数と上下流のエネルギー差との関係は, 羽根の長さが0.12mのときの実験值とほぼ一致した. 水 車の下流側の水深として真值が得られているとすると,
いずれの回転数においても上流側の水深 (図-7) は実験結 果よりも $0.015 \mathrm{~m}$ 程度高いことになる. このような違いが 生じた原因として，MPS法に特有の圧力の擾乱 ${ }^{11)} の$ 影響 によって, 水車の羽根が流れに及ぼす影響が過大に生じ たこと, 鉛直2次元解析のため, 水車と水路側壁の隙間 （2. (3)）の影響が反映されなかったこと, 単相流解析 を行ったため, 気泡の影響を評価できなかったこと (3. (1))等が考えられる. また, 実験尚では, 水車の上下流 の水深は水車の中心から上下流に $2 \mathrm{~m}$ の地点で計測され ており, 水深の評価地点の違いの影響を受けている可能 性もある. 一方で, 解析結果は実験結果と比較して関係 性が全くみられなかったわけではない。このため，上記 の課題を改善すれば, MPS法によって, 水車の設置が開 水路の流れに及ぼす影響の定量的な予測が可能になると 考えられる.

\section{4. 結論}

本研究では，用水路のうち開水路部分に設置される水 車として代表的なものの一つと考えられる流し掛け水車 に着目し, 水車の設置が開水路の流れに及ぼす影響を予 測する方法として，MPS法の適用性を検討を行った，そ の結果, 水車の回転数の違いによる瞬間的な流況につい ては，定性的ではあるが，実験結果とほぼ同様であった。 また, 回転数の減少に伴い, 水車の上流側の水深は水車 設置前よりも大きくなる現象が再現された，一方で，水 


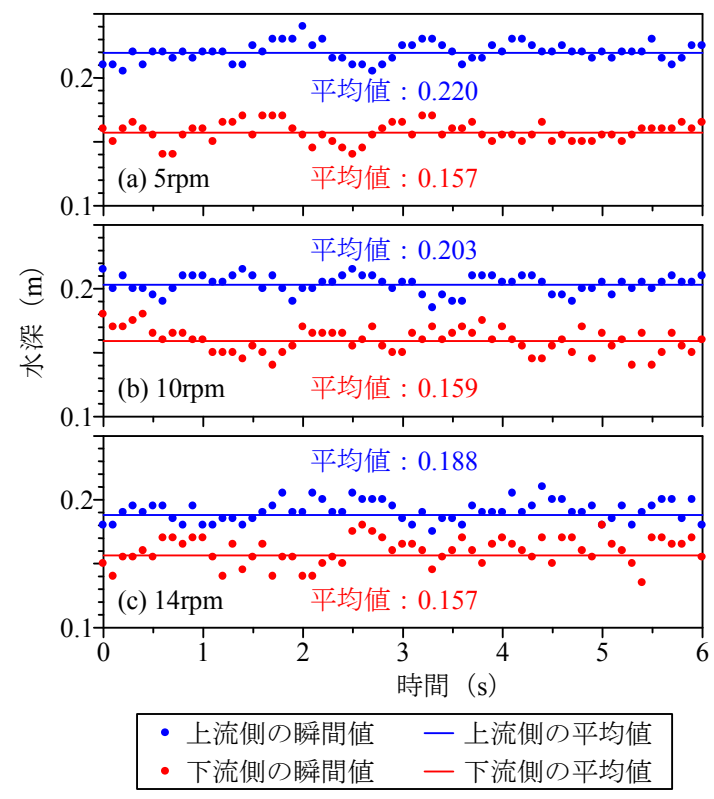

図-7 水車の上下流の水深の経時変化

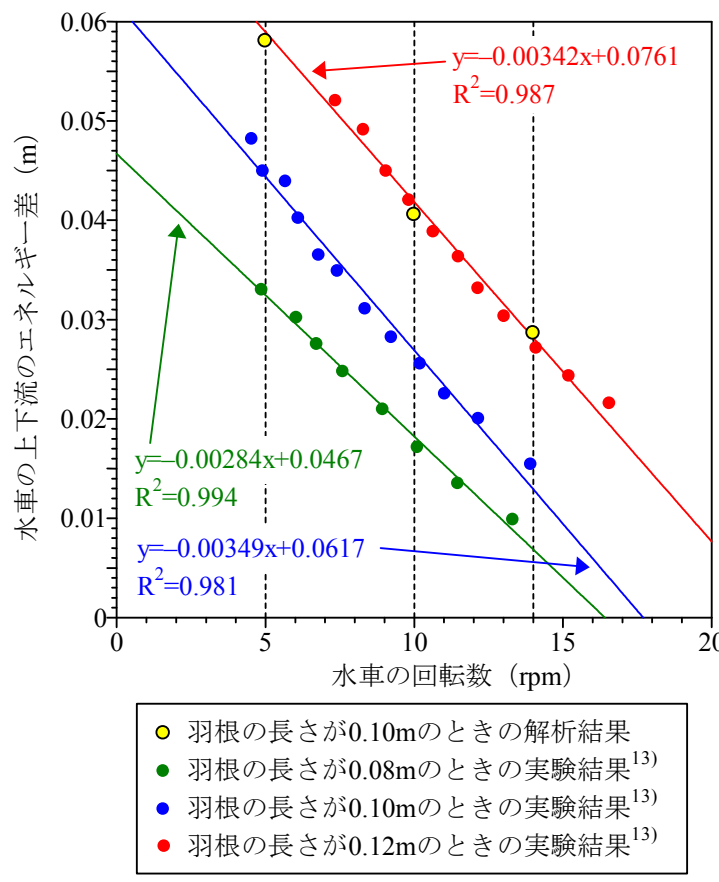

図-8＼cjkstart水車の上下流のエネルギ一差

車の回転数と水車の上下流のエネルギー差との関係は, 水車の羽根を $0.10 \mathrm{~m}$ とて解析したにもかかわらず, $0.12 \mathrm{~m}$ とた実験結果とほぼ一致した。 この原因として, MPS法に特有の圧力の擾乱の影響によって水車の羽根が 流れに及ぼす影響が過大に生じたこと，鉛直2次元解析 を行ったこと，単相流解析を行ったこと等が考えられる. 定性的には現象が十分に再現されているので，これらの 課題を改善寸れば，MPS法によって，水車の設置が開水 路の流れに及ぼす影響の定量的な予測が可能になると考 えられる．特に圧力の擾乱については，近年ではこれを 大幅に低減しうるMPS法の高精度化の研究が進んでいる
ので(1), 17)，それらを参考としたい.

\section{参考文献}

1) 農林水産省ホームページ : 水土とは?, http://www.maff.go.jp/j/nousin/sekkei/suidozu/s_suido/index.html

2) 星野恵美子 : 那須野ヶ原用水における小水力発電事業につ いて, 平成18年度 農業土木学会大会講演会 講演要旨集, pp.106-107, 2006.（http://soil.en.a.u-tokyo.ac.jp/jsidre/ search/ $\mathrm{PDFs} / 06 / 06 \mathrm{~S} 15-02 . \mathrm{pdf})$

3) 農林水産省農村振興局 : 土地改良事業計画設計基準及び運 用・解説 設計「水路工」, 農業農村工学会, pp.199-205, 2001.

4) 長藤友健, 森井啓臣 : フランシス水車内部流れの研究(第3 報 三次元有限要素法によるランナの流孔解析)，日本機械学 会論文集 (B編)，50(450)，pp.398-405，1980.

5) 谷口伸行, 小林敏雄, 長藤友健, 鈴木敏曉, 島田尚子 : 水 車ステーベーン，ガイドベーン周りの3次元流机解析，生産 研究, 43(1), pp.53-56, 1991.

6) 荒川忠一, 銭逸, 久保田喬 : 疑似圧縮性解放によるフラン シス水車ランナの乱流数值解析, 日本機械学会論文集 (B編), 60(573), pp.1661-1668, 1994.

7) 越塚誠一 : 粒子法，丸善，2005.

8) 中西裕二, 藤井恒彰 : 粒子法によるペルトン水車バケット 内の流れの解析(第1 報 相対軌跡を利用した1枚の回転バケッ 卜内の流れ)，日本機械学会論文集 (B編)，73(728)，2007.

9) 中西裕二, 藤井恒彰, 和智恒機 : 粒子法によるペルトン水 車バケット内の流れの解析 (第2 報 非設計点における流れと ランナ出力)，日本機械学会論文集(B編)，73(736)，2007.

10)五十里洋行 : 粒子法による自由表面流の数值解析とその水 工学への応用に関する研究，京都大学学位論文，2007.

11)後藤仁志 : 粒子法による数值波動水槽の構築，水工学に関 寸る夏期研修会講義集，pp.B-3-1 - B-3-20， 2007.

12)近澤佳隆，越塚誠一，岡芳明：MPS法を用いた液面と構造 物の大変形を伴うスロッシングの数值解析, 日本機械学会論 文集(B編)，65(637)，pp.2954-2960，2000。

13)後藤眞宏 : 流し掛け水車の水理特性と流水エネルギー変換 技術に関する研究，農業工学研究所所報, 39, pp.161-196, 2000. (http://agriknowledge.affrc.go.jp/RN/2010611099.pdf)

14)出水力 : 水車の技術史, 思文閣出版, 1987.

15)Gotoh, H., Shibahara, T., Sakai, T. : Sub-particle-scale turbulence model for the MPS method - Lagrangian flow model for hydraulic engineering -, Comp. Fluid Dyn. J., 9-4, pp.339-347, 2001.

16)Khayyer, A. and Gotoh, H. : Modified Moving Particle Semiimplicit methods for the prediction of 2D wave impact pressure, Coastal Eng., 56, pp.419-440, 2009.

17)Khayyer, A. and Gotoh, H. : A higher order laplacian model for enhancement and stabilization of pressure calculation by the MPS method, Applied Ocean Res., 32, pp.124-131, 2010.

（2012. 9. 30受付） 